\title{
Rural Pennsylvania Underemployment And Its Determinants
}

Jack D. Julian, Jr., Ph.D., Indiana University of Pennsylvania, USA

C. Elizabeth Hall, Indiana University of Pennsylvania, USA

David B. Yerger, Ph.D., Indiana University of Pennsylvania, USA

\begin{abstract}
This paper investigates the impact of age distribution and educational attainment on the level of underemployment in Appalachian regions of the United States. Furthermore, this study shows the similarities and differences at the state and county levels for Pennsylvania. Following the methodology of Price and Wail (2005) linear regression models are used to estimate the marginal impacts of general economic conditions measured by the unemployment rate, as well as age and educational attainment, on the level of underemployment in the state. In rural Appalachia, younger workers and those with some post-baccalaureate education are more likely to find themselves underemployed. Keywords: rural economics, Appalachian studies, unemployment, underemployment, measurement issues.
\end{abstract}

\section{INTRODUCTION}

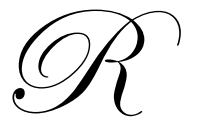

ural unemployment rates persistently have run higher than the national average for many years. In addition, multiple studies have established that rural underemployment also remains a long-running problem. Examples of earlier research documenting the rural underemployment and unemployment problem include work by Ham (1982) and Lichter and Costanzo (1987). Since 1990, a growing literature has examined rural labor market outcomes. Studies by Isserman and Rephamm (1993), Hamrick (1997), and Jensen, Findis, and Wang (1999), among others, have identified several contributing factors to higher rural unemployment and underemployment. These factors include the declining importance of manufacturing and natural resource sectors, lagging educational attainment in rural areas, lower levels of public services support than in urban areas, and geographic isolation.

State government programs to reduce rural unemployment and underemployment reflect the above determinates of poor labor market outcomes. State economic development programs aimed at attracting or retaining employers in the state's rural counties are addressing the job demand side of rural labor markets. State support for education and skill training in rural areas is intended to increase the supply of higher skilled workers in these regions, thereby improving the quality of the labor supply in rural markets and hopefully stimulating greater demand for rural labor services. Lastly, there is a collection of government programs such as child care assistance, disability assistance, and transportation services that can be thought of as helping to eliminate barriers preventing potential workers from joining the labor force in rural areas.

Unfortunately, it is not yet fully understood how the various factors contributing to rural unemployment and underemployment interact to adversely affect rural labor markets. This lack of understanding regarding the most important determinates of rural unemployment and underemployment, and their interactive effects, complicates the targeting of scarce public tax dollars on programs most likely to improve rural labor markets.

This study modifies the Price and Wial (2005) estimates to focus solely upon the underemployment rates. A model is developed similar to that of Bollinger, Coomes, and Berger (2003) which is used to explain variations across Pennsylvania counties in their estimated underemployment rates by variations in county-level age distributions, educational attainment, and urban/rural status. 


\section{METHODOLOGY AND DATA}

A linear regression model is used to estimate each Pennsylvania county's number of underemployed workers and analyze recent trends. This is calculated using the estimated impact of each of the variables on underemployment from the regression model and the data on the percentage of adult population in the county belonging to each socio-demographic category along with county labor market outcome data. This model allows one to estimate changes in county underemployment rates associated with changes in the reported unemployment rates thereby providing a reasonably straightforward way to more comprehensively track changes in county labor market conditions.

Price and Wail (2005) construct substate-level estimates of underemployment for urban and rural areas in each of the thirteen Appalachian states. Their underemployment estimates were computed directly from the Current Population Survey extracts. Price and Wail define underemployment as the official unemployment rate from the Bureau of Labor Statistics plus involuntary part-time workers, discouraged workers, and other marginally attached workers, all based on Bureau of Labor Statistics classifications. Rather than provide county-level estimates, Price and Wail divide each Appalachian state into four groups: rural Appalachian, metropolitan (or urban) Appalachian, rural non-Appalachian, and metropolitan (or urban) Appalachian. In order to separate the observed unemployment rate from the other underemployment measures, this study aggregates the county-level unemployment data into Price and Wail's substate groupings. Then the unemployment rate is subtracted from Price and Wail's underemployment rate measure yielding the net underemployment measure used here (involuntary part-time workers, discouraged workers, and other marginally attached workers). Table 1 summarizes the unemployment rate and underemployment and compares the Pennsylvania outcomes against those of other Appalachian states, the most relevant comparison group for rural Pennsylvania.

Table 1: Summary Statistics on Underemployment, Unemployment, and Demographic Variables: All Appalachian States and Pennsylvania, 1996-2004

Top row: Entire cohort averages (standard deviations in parenthesis). Bottom row: Pennsylvania Averages

\begin{tabular}{|c|c|c|c|c|}
\hline \multirow[b]{2}{*}{ Variable } & \multicolumn{2}{|c|}{ Appalachian } & \multicolumn{2}{|c|}{ Non-Appalachian } \\
\hline & Rural & Urban & Rural & Urban \\
\hline Underemployment rate & $\begin{array}{l}.034(.018) \\
.035\end{array}$ & $\begin{array}{l}.028(.021) \\
.039\end{array}$ & $\begin{array}{l}.042(.014) \\
.053\end{array}$ & $\begin{array}{l}.035(.010) \\
.037\end{array}$ \\
\hline Unemployment rate & $\begin{array}{l}.062(.012) \\
.062\end{array}$ & $\begin{array}{l}.048(.011) \\
.053\end{array}$ & $\begin{array}{l}.059(.012) \\
.042 * *\end{array}$ & $\begin{array}{l}.044(.010) \\
.046\end{array}$ \\
\hline Share of population 15-19 & $\begin{array}{l}.090(.009) \\
.088\end{array}$ & $\begin{array}{l}.088(.009) \\
.082\end{array}$ & $\begin{array}{l}.092(.009) \\
.086\end{array}$ & $\begin{array}{l}.091(.007) \\
.086\end{array}$ \\
\hline Share of population $20-34$ & $\begin{array}{l}.247(.016) \\
.228 * *\end{array}$ & $\begin{array}{l}.260(.025) \\
.228 * *\end{array}$ & $\begin{array}{l}.249(.017) \\
.238\end{array}$ & $\begin{array}{l}.281(.021) \\
.247 * *\end{array}$ \\
\hline Share of population $35-54$ & $\begin{array}{l}.355(.011) \\
.358\end{array}$ & $\begin{array}{l}.365(.021) \\
.360\end{array}$ & $\begin{array}{l}.359(.012) \\
.365\end{array}$ & $\begin{array}{l}.377(.011) \\
.374\end{array}$ \\
\hline Share of population 55+ & $\begin{array}{l}.313(.020) \\
.327\end{array}$ & $\begin{array}{l}.292(.030) \\
.330 *\end{array}$ & $\begin{array}{l}.305(.023) \\
.310\end{array}$ & $\begin{array}{l}.256(.023) \\
.293 *\end{array}$ \\
\hline $\begin{array}{l}\text { Fraction of population not } \\
\text { completing high school }\end{array}$ & $\begin{array}{l}.289(.057) \\
.204 * *\end{array}$ & $\begin{array}{l}.213(.030) \\
.161 * *\end{array}$ & $\begin{array}{l}.270(.044) \\
.213 * *\end{array}$ & $\begin{array}{l}.195(.021) \\
.191\end{array}$ \\
\hline $\begin{array}{l}\text { Fraction of population } \\
\text { with high school } \\
\text { diploma only } \\
\end{array}$ & $\begin{array}{l}.363(.047) \\
.458^{*}\end{array}$ & $\begin{array}{l}.335(.048) \\
.387 *\end{array}$ & $\begin{array}{l}.360(.046) \\
.436^{*}\end{array}$ & $\begin{array}{l}.286(.027) \\
.334^{*}\end{array}$ \\
\hline $\begin{array}{c}\begin{array}{c}\text { Fraction of population } \\
\text { with some college }\end{array} \\
\end{array}$ & $\begin{array}{l}.233(.031) \\
.211\end{array}$ & $\begin{array}{l}.274(.024) \\
.252\end{array}$ & $\begin{array}{l}.240(.021) \\
.207 * *\end{array}$ & $\begin{array}{l}.282(.021) \\
.234 * *\end{array}$ \\
\hline $\begin{array}{r}\text { Fraction of population } \\
\text { with college degree }\end{array}$ & $\begin{array}{l}.073(.012) \\
.082\end{array}$ & $\begin{array}{l}.114(.024) \\
.129\end{array}$ & $\begin{array}{l}.084(.009) \\
.089\end{array}$ & $\begin{array}{l}.152(.021) \\
.153\end{array}$ \\
\hline $\begin{array}{l}\text { Fraction of population } \\
\text { with some } \\
\text { postgraduate education }\end{array}$ & $\begin{array}{l}.042(.008) \\
.045\end{array}$ & $\begin{array}{l}.065(.015) \\
.070\end{array}$ & $\begin{array}{l}.046(.008) \\
.056^{*}\end{array}$ & $\begin{array}{l}.084(.020) \\
.087\end{array}$ \\
\hline
\end{tabular}


Based on the Price and Wail geographic classifications, how does rural Pennsylvania compare with other rural areas within the Appalachian states? Rural unemployment and underemployment are essentially the same for rural Appalachian Pennsylvania as they are for the rest of rural Appalachia. The unemployment rate averages 6.2 percent for both the entire cohort rural Appalachia as well as for rural Pennsylvania, while the underemployment rate is 3.4 percent and 3.5 percent respectively. When comparing the non-Appalachian rural counties, Pennsylvania has a higher underemployment rate (5.3 percent vs. 4.2 percent) but a lower unemployment rate ( 4.2 percent vs. 5.9 percent) compared to the entire non-Appalachian rural cohort.

Table 1 also summarizes several key demographic variables: age and educational attainment. Age distribution of the population is measured as the fraction ages 15-19, 20-34, 35-54, 55 and higher. It is clear that rural Pennsylvania lags the rest of rural Appalachia in the share of its populace in the 20-34 age cohort while exceeding the rest of rural Appalachia in the 55 and higher cohort.

Educational attainment of the population is measured as the fraction with less than a high school diploma, high school graduates, some college, college degree, and postgraduate education. Rural Pennsylvania has a notably lower fraction of populace without a high school diploma than the rural Appalachian average. Rural Pennsylvania also has a slightly higher fraction of the population with a college degree.

\section{REGRESSION ANALYSIS}

To what extent are the differences in underemployment across the regions defined by Price and Wail due to variations in the age and educational attainment of the populations? The importance of these two forces for explaining variations in the underemployment rate is estimated through the use of a statistical regression analysis over the years 1996 to 2004 (the range of data available from Price and Wail). The regression analysis assesses the role of differences across the four substate regions within each Appalachian state in their share of adult population in different educational attainment and age categories in explaining differences across their underemployment rates. The unemployment rate is also included to account for fluctuations in labor demand. It would be expected that higher unemployment rates would be associated with higher rates of underemployment due to weaker labor demand. A summary of the regression analysis is found in Table 2. A separate ordinary least squares linear regression was estimated for each region.

The estimates measure the marginal effect of a one percentage point change in the education and age variables upon the underemployment rate. Parameter estimates are noted for their statistical significance in the table by the appropriate asterisk, denoting the variable's explanatory impact on the underemployment rate. For example, a one percentage point rise in the share of population ages 15 to 19 in a rural Appalachian region is associated with a 1.327 percentage point rise in the region's underemployment rate (say from 3.0 percent to 4.327 percent).

The unemployment rate has no explanatory power in the areas designated Appalachian, whereas it is positive and statistically significant for both rural and urban areas of non-Appalachian regions. An increase of 1.0 percentage point in the unemployment rate raises the underemployment rate by 0.192 percentage point in rural areas and 0.322 percentage point in urban non-Appalachian areas.

More prominently, explanatory power is found in the educational attainment variables. Relative to the reference group (those in the work force with just a high school diploma) the higher the fraction of the rural workforce that have less than a high school diploma the lower the underemployment rate, but the effect is small: a 1.0 percentage point rise in the fraction of population not completing high school is associated with a decline of only 0.06 percentage points in the underemployment rate for rural Appalachian regions. (There is no measurably significant impact of this variable on urban workers' underemployment rates.) Perhaps because they may have fewer employable skills these workers are less likely to consider themselves as underemployed. Also, to the extent that the cost of living is lower in rural areas (Kurre 2000), they have the ability to generate sufficient incomes to not regard themselves as underemployed. 
Table 2: Estimated Effects of Unemployment Rate and Demographic Variables on Underemployment, 1996-2004

\begin{tabular}{|c|c|c|c|c|}
\hline & \multicolumn{2}{|c|}{ Appalachian } & \multicolumn{2}{|c|}{ Non-Appalachian } \\
\hline & Rural & Urban & Rural & Urban \\
\hline Unemployment rate & $\begin{array}{l}-.033 \\
(-.254)\end{array}$ & $\begin{array}{c}.007 \\
(-.035)\end{array}$ & $\begin{array}{c}.192 * \\
(1.352)\end{array}$ & $\begin{array}{l}.322 * * * \\
(2.455)\end{array}$ \\
\hline $\begin{array}{l}\text { Share of population 15- } \\
19^{1}\end{array}$ & $\begin{array}{c}1.327 * * * \\
(4.654)\end{array}$ & $\begin{array}{l}-.001 \\
(-.001) \\
\end{array}$ & $\begin{array}{l}.153 \\
(.854) \\
\end{array}$ & $\begin{array}{l}.314^{*} \\
(1.329)\end{array}$ \\
\hline $\begin{array}{l}\text { Share of population 20- } \\
\quad 34^{1}\end{array}$ & $\begin{array}{l}.667 * * * \\
(4.985)\end{array}$ & $\begin{array}{c}.209^{*} \\
(1.452)\end{array}$ & $\begin{array}{l}.343 * * \\
(2.336)\end{array}$ & $\begin{array}{c}.110 \\
(1.214)\end{array}$ \\
\hline $\begin{array}{l}\text { Share of population } \\
55+{ }^{1}\end{array}$ & $\begin{array}{l}.826 * * * \\
(5.859) \\
\end{array}$ & $\begin{array}{c}.321 * \\
(2.753) \\
\end{array}$ & $\begin{array}{l}.051 \\
(.587) \\
\end{array}$ & $\begin{array}{l}.093 \\
(.940) \\
\end{array}$ \\
\hline $\begin{array}{l}\text { Fraction of population } \\
\text { not completing high } \\
\text { school }^{2}\end{array}$ & $\begin{array}{c}-.060 * \\
(-1.481)\end{array}$ & $\begin{array}{l}-.034 \\
(-.344)\end{array}$ & $\begin{array}{l}-.077 * * \\
(-2.111)\end{array}$ & $\begin{array}{l}-.031 \\
(-.351)\end{array}$ \\
\hline $\begin{array}{l}\text { Fraction of population } \\
\text { with some college }{ }^{2}\end{array}$ & $\begin{array}{l}-.500 * * * \\
(-5.462) \\
\end{array}$ & $\begin{array}{l}-.275 * * \\
(-1.758) \\
\end{array}$ & $\begin{array}{c}-.080 \\
(-1.089)\end{array}$ & $\begin{array}{l}.046 \\
(.579) \\
\end{array}$ \\
\hline $\begin{array}{l}\text { Fraction of population } \\
\text { with college degree }^{2}\end{array}$ & $\begin{array}{l}-.094 \\
(-.445)\end{array}$ & $\begin{array}{l}.360 * * * \\
(2.853)\end{array}$ & $\begin{array}{l}.161 \\
(.968)\end{array}$ & $\begin{array}{l}-.087 \\
(-.771)\end{array}$ \\
\hline $\begin{array}{l}\text { Fraction of population } \\
\text { with some } \\
\text { postgraduate } \\
\text { education }\end{array}$ & $\begin{array}{c}1.411 * * * \\
(4.744)\end{array}$ & $\begin{array}{l}.440 * * \\
(1.708)\end{array}$ & $\begin{array}{l}.344 * * \\
(1.709)\end{array}$ & $\begin{array}{l}.129 * \\
(1.492)\end{array}$ \\
\hline Constant & $\begin{array}{l}-.425 * * * \\
(-5.274)\end{array}$ & $\begin{array}{c}-.108 * \\
(-1.506)\end{array}$ & $\begin{array}{c}-.073 * \\
(-1.390)\end{array}$ & $\begin{array}{c}-.067 \\
(-1.082)\end{array}$ \\
\hline $\begin{array}{l}\text { R-square } \\
\mathrm{F} \\
\mathrm{n}\end{array}$ & $\begin{array}{c}0.427 \\
8.395 * * * \\
99\end{array}$ & $\begin{array}{c}.344 \\
6.492 * * * \\
108\end{array}$ & $\begin{array}{c}.248 \\
3.742 * * * \\
100\end{array}$ & $\begin{array}{c}.192 \\
2.946^{* * *} \\
108\end{array}$ \\
\hline
\end{tabular}

The higher the fraction of workers with some college is also associated with lower underemployment rates for those in Appalachian areas, both rural and urban (no measurably significant impact in non-Appalachian areas). There is some indication of an underemployment problem in rural Appalachia for highly educated individuals as seen in the estimated impact upon underemployment from a rise in the fraction of population with some postgraduate education. For rural Appalachia, a one percentage point rise in the fraction of populace with some postgraduate education is associated with a 1.411 percentage point rise in the underemployment rate.

\section{ESTIMATES OF UNDEREMPLOYMENT RATES AT THE COUNTY LEVEL}

Using the estimated impact of the unemployment rate, education, and age variables upon underemployment rates from the regression analysis reported in Table 2, county-specific underemployment rate estimates are computed for Pennsylvania for 1996 to 2004 and are listed in Table 3. The reported underemployment percentages are expressed as a fraction of the county's labor force.

When interpreting the results found in Table 3, it is important to remember that these estimates are based on the general relationship between the underemployment rate and the explanatory variables (unemployment, education, and age). It is possible for any one county to deviate from this general relationship. For example, it is doubtful that Montour County has the highest underemployment rate of any county in the state. This result likely is due to a relatively high concentration of adults with postgraduate education in the county due to Geisinger Medical Center. It is unlikely these health care professionals are underemployed. 
Table 3: Estimates of Underemployment by Pennsylvania County 1996-2004

\begin{tabular}{|c|c|c|c|c|c|c|c|c|c|}
\hline & 1996 & 1997 & 1998 & 1999 & 2000 & 2001 & 2002 & 2003 & 2004 \\
\hline Adams & $5.4 \%$ & $5.2 \%$ & $4.9 \%$ & $4.7 \%$ & $4.5 \%$ & $4.6 \%$ & $4.8 \%$ & $4.9 \%$ & $4.9 \%$ \\
\hline Allegheny & $7.7 \%$ & $7.6 \%$ & $7.5 \%$ & $7.4 \%$ & $7.3 \%$ & $7.2 \%$ & $7.3 \%$ & $7.3 \%$ & $7.4 \%$ \\
\hline Armstrong & $2.6 \%$ & $2.5 \%$ & $2.4 \%$ & $2.3 \%$ & $2.3 \%$ & $2.2 \%$ & $2.5 \%$ & $2.6 \%$ & $2.7 \%$ \\
\hline Beaver & $2.7 \%$ & $2.6 \%$ & $2.5 \%$ & $2.5 \%$ & $2.4 \%$ & $2.4 \%$ & $2.5 \%$ & $2.6 \%$ & $2.7 \%$ \\
\hline Bedford & $4.4 \%$ & $4.3 \%$ & $4.3 \%$ & $4.2 \%$ & $4.0 \%$ & $3.6 \%$ & $3.8 \%$ & $3.9 \%$ & $4.1 \%$ \\
\hline Berks & $3.1 \%$ & $3.0 \%$ & $3.0 \%$ & $2.9 \%$ & $2.8 \%$ & $3.0 \%$ & $3.5 \%$ & $3.5 \%$ & $3.4 \%$ \\
\hline Blair & $3.1 \%$ & $3.0 \%$ & $3.0 \%$ & $2.9 \%$ & $2.9 \%$ & $3.0 \%$ & $3.2 \%$ & $3.4 \%$ & $3.5 \%$ \\
\hline Bradford & $5.8 \%$ & $5.8 \%$ & $5.9 \%$ & $5.9 \%$ & $5.8 \%$ & $5.5 \%$ & $5.6 \%$ & $5.9 \%$ & $6.3 \%$ \\
\hline Bucks & $3.0 \%$ & $2.9 \%$ & $2.7 \%$ & $2.6 \%$ & $2.5 \%$ & $2.7 \%$ & $3.0 \%$ & $3.0 \%$ & $3.0 \%$ \\
\hline Butler & $4.1 \%$ & $4.0 \%$ & $4.0 \%$ & $3.9 \%$ & $3.8 \%$ & $3.8 \%$ & $4.0 \%$ & $4.1 \%$ & $4.2 \%$ \\
\hline Cambria & $3.7 \%$ & $3.6 \%$ & $3.5 \%$ & $3.5 \%$ & $3.4 \%$ & $3.4 \%$ & $3.5 \%$ & $3.6 \%$ & $3.7 \%$ \\
\hline Cameron & $6.7 \%$ & $6.6 \%$ & $6.8 \%$ & $6.5 \%$ & $6.5 \%$ & $6.0 \%$ & $6.4 \%$ & $6.8 \%$ & $6.9 \%$ \\
\hline Carbon & $2.8 \%$ & $2.7 \%$ & $2.6 \%$ & $2.5 \%$ & $2.3 \%$ & $2.3 \%$ & $2.4 \%$ & $2.4 \%$ & $2.5 \%$ \\
\hline Centre & $4.8 \%$ & $4.7 \%$ & $4.8 \%$ & $4.8 \%$ & $4.9 \%$ & $5.1 \%$ & $5.2 \%$ & $5.4 \%$ & $5.7 \%$ \\
\hline Chester & $2.6 \%$ & $2.5 \%$ & $2.3 \%$ & $2.3 \%$ & $2.4 \%$ & $2.5 \%$ & $2.8 \%$ & $2.8 \%$ & $2.8 \%$ \\
\hline Clarion & $7.7 \%$ & $7.6 \%$ & $7.6 \%$ & $7.5 \%$ & $7.3 \%$ & $7.0 \%$ & $6.9 \%$ & $7.3 \%$ & $6.8 \%$ \\
\hline Clearfield & $5.1 \%$ & $4.8 \%$ & $4.8 \%$ & $4.6 \%$ & $4.3 \%$ & $3.8 \%$ & $4.0 \%$ & $4.1 \%$ & $4.3 \%$ \\
\hline Clinton & $5.5 \%$ & $5.4 \%$ & $5.4 \%$ & $5.7 \%$ & $5.6 \%$ & $5.5 \%$ & $5.7 \%$ & $6.1 \%$ & $6.0 \%$ \\
\hline Columbia & $6.1 \%$ & $5.9 \%$ & $5.9 \%$ & $5.6 \%$ & $5.4 \%$ & $5.3 \%$ & $5.7 \%$ & $6.0 \%$ & $6.2 \%$ \\
\hline Crawford & $5.7 \%$ & $5.6 \%$ & $5.6 \%$ & $5.5 \%$ & $5.4 \%$ & $5.2 \%$ & $5.2 \%$ & $5.5 \%$ & $5.9 \%$ \\
\hline Cumberland & $3.0 \%$ & $2.9 \%$ & $2.8 \%$ & $2.9 \%$ & $2.9 \%$ & $3.1 \%$ & $3.3 \%$ & $3.3 \%$ & $3.3 \%$ \\
\hline Dauphin & $2.6 \%$ & $2.6 \%$ & $2.4 \%$ & $2.6 \%$ & $2.5 \%$ & $2.7 \%$ & $2.9 \%$ & $3.0 \%$ & $3.0 \%$ \\
\hline Delaware & $3.9 \%$ & $3.7 \%$ & $3.5 \%$ & $3.4 \%$ & $3.4 \%$ & $3.5 \%$ & $3.8 \%$ & $3.9 \%$ & $3.9 \%$ \\
\hline Elk & $3.5 \%$ & $3.3 \%$ & $3.4 \%$ & $3.2 \%$ & $2.9 \%$ & $2.4 \%$ & $2.5 \%$ & $2.5 \%$ & $2.5 \%$ \\
\hline Erie & $3.9 \%$ & $3.7 \%$ & $3.7 \%$ & $3.6 \%$ & $3.6 \%$ & $3.6 \%$ & $3.8 \%$ & $3.9 \%$ & $4.1 \%$ \\
\hline Fayette & $3.6 \%$ & $3.5 \%$ & $3.5 \%$ & $3.4 \%$ & $3.3 \%$ & $3.4 \%$ & $3.5 \%$ & $3.6 \%$ & $3.6 \%$ \\
\hline Forest & $9.7 \%$ & $10.2 \%$ & $10.8 \%$ & $11.1 \%$ & $11.2 \%$ & $11.9 \%$ & $11.9 \%$ & $12.3 \%$ & $9.7 \%$ \\
\hline Franklin & $4.9 \%$ & $4.7 \%$ & $4.4 \%$ & $4.4 \%$ & $4.1 \%$ & $4.2 \%$ & $4.3 \%$ & $4.2 \%$ & $4.2 \%$ \\
\hline Fulton & $4.8 \%$ & $4.6 \%$ & $4.8 \%$ & $4.8 \%$ & $4.6 \%$ & $4.4 \%$ & $4.8 \%$ & $5.0 \%$ & $5.4 \%$ \\
\hline Greene & $4.8 \%$ & $4.4 \%$ & $4.3 \%$ & $3.9 \%$ & $3.4 \%$ & $3.2 \%$ & $3.3 \%$ & $3.7 \%$ & $4.1 \%$ \\
\hline Huntingdon & $4.9 \%$ & $4.8 \%$ & $4.9 \%$ & $4.8 \%$ & $4.7 \%$ & $4.5 \%$ & $5.0 \%$ & $5.3 \%$ & $5.5 \%$ \\
\hline Indiana & $7.4 \%$ & $7.3 \%$ & $7.3 \%$ & $7.1 \%$ & $7.0 \%$ & $6.9 \%$ & $6.9 \%$ & $7.0 \%$ & $7.2 \%$ \\
\hline Jefferson & $5.6 \%$ & $5.5 \%$ & $5.5 \%$ & $5.3 \%$ & $5.1 \%$ & $4.7 \%$ & $4.7 \%$ & $4.7 \%$ & $4.7 \%$ \\
\hline Juniata & $4.1 \%$ & $4.1 \%$ & $4.1 \%$ & $4.2 \%$ & $3.9 \%$ & $3.7 \%$ & $3.8 \%$ & $4.3 \%$ & $4.9 \%$ \\
\hline Lackawanna & $5.4 \%$ & $5.2 \%$ & $5.2 \%$ & $5.1 \%$ & $5.0 \%$ & $5.0 \%$ & $5.1 \%$ & $5.1 \%$ & $5.1 \%$ \\
\hline Lancaster & $2.6 \%$ & $2.5 \%$ & $2.4 \%$ & $2.4 \%$ & $2.4 \%$ & $2.5 \%$ & $2.6 \%$ & $2.7 \%$ & $2.7 \%$ \\
\hline Lawrence & $5.5 \%$ & $5.3 \%$ & $5.3 \%$ & $5.0 \%$ & $4.9 \%$ & $4.6 \%$ & $4.8 \%$ & $4.9 \%$ & $5.1 \%$ \\
\hline Lebanon & $2.8 \%$ & $2.6 \%$ & $2.6 \%$ & $2.5 \%$ & $2.5 \%$ & $2.5 \%$ & $2.7 \%$ & $2.8 \%$ & $2.7 \%$ \\
\hline Lehigh & $3.3 \%$ & $3.1 \%$ & $3.0 \%$ & $2.9 \%$ & $2.7 \%$ & $3.0 \%$ & $3.4 \%$ & $3.4 \%$ & $3.4 \%$ \\
\hline Luzerne & $4.0 \%$ & $3.9 \%$ & $3.8 \%$ & $3.7 \%$ & $3.6 \%$ & $3.6 \%$ & $3.7 \%$ & $3.7 \%$ & $3.7 \%$ \\
\hline Lycoming & $1.8 \%$ & $1.7 \%$ & $1.7 \%$ & $1.7 \%$ & $1.6 \%$ & $1.7 \%$ & $1.9 \%$ & $2.0 \%$ & $2.1 \%$ \\
\hline McKean & $5.3 \%$ & $5.1 \%$ & $5.1 \%$ & $4.8 \%$ & $4.6 \%$ & $4.5 \%$ & $4.4 \%$ & $4.6 \%$ & $4.6 \%$ \\
\hline Mercer & $4.2 \%$ & $4.1 \%$ & $4.1 \%$ & $4.0 \%$ & $4.0 \%$ & $4.0 \%$ & $4.1 \%$ & $4.2 \%$ & $4.3 \%$ \\
\hline Mifflin & $6.8 \%$ & $6.7 \%$ & $6.9 \%$ & $6.9 \%$ & $6.9 \%$ & $6.4 \%$ & $6.8 \%$ & $7.2 \%$ & $7.4 \%$ \\
\hline Monroe & $1.4 \%$ & $1.1 \%$ & $1.0 \%$ & $0.7 \%$ & $0.4 \%$ & $0.4 \%$ & $1.0 \%$ & $1.5 \%$ & $1.8 \%$ \\
\hline Montgomery & $3.0 \%$ & $2.9 \%$ & $2.7 \%$ & $2.6 \%$ & $2.6 \%$ & $2.8 \%$ & $3.2 \%$ & $3.2 \%$ & $3.1 \%$ \\
\hline Montour & $13.2 \%$ & $13.0 \%$ & $13.0 \%$ & $12.9 \%$ & $12.7 \%$ & $12.5 \%$ & $12.7 \%$ & $12.6 \%$ & $13.1 \%$ \\
\hline Northampton & $3.7 \%$ & $3.5 \%$ & $3.3 \%$ & $3.1 \%$ & $3.0 \%$ & $3.1 \%$ & $3.5 \%$ & $3.6 \%$ & $3.6 \%$ \\
\hline Northumberland & $5.8 \%$ & $5.6 \%$ & $5.6 \%$ & $5.4 \%$ & $5.2 \%$ & $4.8 \%$ & $5.0 \%$ & $5.0 \%$ & $5.1 \%$ \\
\hline Perry & $1.0 \%$ & $0.9 \%$ & $0.9 \%$ & $0.9 \%$ & $0.9 \%$ & $0.9 \%$ & $1.2 \%$ & $1.4 \%$ & $1.6 \%$ \\
\hline Philadelphia/city & $4.4 \%$ & $4.3 \%$ & $4.2 \%$ & $4.1 \%$ & $3.9 \%$ & $4.0 \%$ & $4.4 \%$ & $4.5 \%$ & $4.5 \%$ \\
\hline Pike & $3.3 \%$ & $3.2 \%$ & $3.0 \%$ & $2.9 \%$ & $2.8 \%$ & $2.6 \%$ & $2.7 \%$ & $2.8 \%$ & $2.8 \%$ \\
\hline Potter & $4.7 \%$ & $4.7 \%$ & $4.8 \%$ & $4.8 \%$ & $4.5 \%$ & $4.2 \%$ & $4.1 \%$ & $4.6 \%$ & $4.9 \%$ \\
\hline Schuylkill & $5.0 \%$ & $4.6 \%$ & $4.5 \%$ & $4.2 \%$ & $3.9 \%$ & $3.5 \%$ & $3.6 \%$ & $3.7 \%$ & $3.8 \%$ \\
\hline Snyder & $5.5 \%$ & $5.2 \%$ & $5.4 \%$ & $5.5 \%$ & $5.4 \%$ & $5.5 \%$ & $5.7 \%$ & $5.9 \%$ & $6.3 \%$ \\
\hline
\end{tabular}


Table 3: Estimates of Underemployment by Pennsylvania County 1996-2004 (continued)

\begin{tabular}{|l|c|c|c|c|c|c|c|c|c|}
\hline Somerset & $5.1 \%$ & $4.8 \%$ & $4.8 \%$ & $4.6 \%$ & $4.4 \%$ & $4.1 \%$ & $4.2 \%$ & $4.3 \%$ & $4.5 \%$ \\
\hline Sullivan & $11.1 \%$ & $11.0 \%$ & $10.9 \%$ & $10.9 \%$ & $10.7 \%$ & $10.5 \%$ & $11.8 \%$ & $11.7 \%$ & $12.2 \%$ \\
\hline Susquehanna & $3.4 \%$ & $3.4 \%$ & $3.6 \%$ & $3.5 \%$ & $3.4 \%$ & $3.1 \%$ & $3.4 \%$ & $3.7 \%$ & $4.0 \%$ \\
\hline Tioga & $5.4 \%$ & $5.4 \%$ & $5.8 \%$ & $5.8 \%$ & $5.7 \%$ & $5.3 \%$ & $5.5 \%$ & $5.7 \%$ & $5.8 \%$ \\
\hline Union & $6.8 \%$ & $6.9 \%$ & $7.4 \%$ & $7.4 \%$ & $7.4 \%$ & $7.2 \%$ & $7.3 \%$ & $8.0 \%$ & $8.1 \%$ \\
\hline Venango & $4.9 \%$ & $4.8 \%$ & $4.9 \%$ & $4.8 \%$ & $4.6 \%$ & $4.4 \%$ & $4.7 \%$ & $5.0 \%$ & $5.1 \%$ \\
\hline Warren & $2.8 \%$ & $2.7 \%$ & $2.8 \%$ & $2.7 \%$ & $2.5 \%$ & $2.5 \%$ & $2.7 \%$ & $2.9 \%$ & $3.2 \%$ \\
\hline Washington & $4.7 \%$ & $4.5 \%$ & $4.5 \%$ & $4.4 \%$ & $4.4 \%$ & $4.3 \%$ & $4.5 \%$ & $4.6 \%$ & $4.7 \%$ \\
\hline Wayne & $4.5 \%$ & $4.2 \%$ & $4.3 \%$ & $4.0 \%$ & $3.8 \%$ & $3.9 \%$ & $4.2 \%$ & $4.3 \%$ & $4.6 \%$ \\
\hline Westmoreland & $4.7 \%$ & $4.6 \%$ & $4.6 \%$ & $4.5 \%$ & $4.5 \%$ & $4.4 \%$ & $4.6 \%$ & $4.7 \%$ & $4.8 \%$ \\
\hline Wyoming & $1.7 \%$ & $1.7 \%$ & $1.7 \%$ & $1.7 \%$ & $1.7 \%$ & $1.7 \%$ & $2.1 \%$ & $2.4 \%$ & $2.6 \%$ \\
\hline York & $2.7 \%$ & $2.5 \%$ & $2.4 \%$ & $2.3 \%$ & $2.2 \%$ & $2.5 \%$ & $2.7 \%$ & $2.7 \%$ & $2.7 \%$ \\
\hline
\end{tabular}

\section{CONCLUSION}

This paper estimates the impact of age distribution and educational attainment and their effects on underemployment in Appalachian regions of the United States. County-specific underemployment rates for each Pennsylvania county were computed based upon statistical regression-based estimates of the linkages between underemployment rates and both the educational and age distribution profiles of a county. The results indicate that underemployment rises as the share of the workforce that is less than 20 years of age rises and as the share that is over 55 years of age rises. Rural underemployment rates also rise as the share of populace with some schooling beyond bachelors degree rises. For 2004, rural county underemployment rates varied from 2.7 percent to more than 10.0 percent with the counties most likely to be suffering from substantial underemployment including Sullivan, Forest, Union, Mifflin, Indiana, Cameron, Clarion, Bradford, Snyder, Columbia, and Clinton with estimated underemployment rates in excess of 6.0 percent. While this paper's empirical emphasis is on Pennsylvania, the techniques and data developed is of interest to researchers investigating the rural underemployment problem elsewhere in Appalachia and the rest of the country.

\section{ACKNOWLEDGEMENT}

This project was made possible, in part, by a grant from the Center for Rural Pennsylvania, a legislative agency of the Pennsylvania General Assembly.

\section{AUTHOR INFORMATION}

Jack Julian is an assistant professor in the Department of Economics at Indiana University of Pennsylvania. He holds a Ph.D. in economics from the University of Cincinnati. He regularly teaches courses in international trade and international finance, as well as principles of micro- and macroeconomics. In addition, his research interests lie in the regional economics of Pennsylvania and in economic education. He as previously served in positions with Centers for Economic Education in Akron, Ohio, and Lincoln, Nebraska.

David Yerger is an associate professor in the Department of Economics at Indiana University of Pennsylvania. He holds a Ph.D. in economics from the Pennsylvania State University. His teaching areas are in macroeconomics and environmental economics. His research areas are in international economics and regional studies in Pennsylvania. He has done policy studies of import competition for the Canadian government. He is a past president of the Pennsylvania Economic Association. He is former editor of the Pennsylvania Economic Review. He continues to serve as a referee for several journals and as a grant reviewer for the Center for Rural Pennsylvania.

Elizabeth Hall is a 2004 graduate of the Indiana University of Pennsylvania with a B.A. in economics/mathematics. While at IUP, she worked as a research assistant to Dr. Jack Julian and Dr. David Yerger on a research project for the Center for Rural Pennsylvania. She currently attends Duke University School of Law where she is a member of the Duke Law Journal and the Public Interest Law Foundation. There, she continues to use her economics background in her work with the North Carolina Commissioner of Banks' State Home Foreclosure Prevention Project. 


\section{REFERENCES}

1. Bollinger, C.R, P. Coomes, and M. Berger. 2003 "Measuring Underemployment at the County Level" Working Paper.

2. Ham, J.C., 1982 "Estimation of a Labour Supply Model with Censoring Due to Unemployment and Underemployment", Review of Economic Studies 49(157), pp. 335-354.

3. Hamrick, K.S. 1997, "Rural Labor Markets Often Lead Urban Markets in Recessions and Expansions", Rural Development Perspectives, 12(3).

4. Isserman, A., and T. Rephann. 1993. "Geographical and Gender Differences in Labor Force Participation: Is There an Appalachian Effect?" Growth and Change 24 (Fall): 539-578.

5. Jensen, L., J. Findeis, Q. Wang. 1999. "Labor Supply and Underemployment in the Southern United States." Paper for Southern Regional Science Association, April 16, 1999, Richmond, VA.

6. Kurre, J.A. 2000. "Differences in the Cost of Living Across Pennsylvania's 67 Counties." Center for Rural Pennsylvania, Harrisburg, PA.

7. Lichter, D. and J. Costanzo. 1987. "Non-metropolitan Underemployment and Labor Force Composition", Rural Sociology 52 (Fall): 329-344.

8. Price, M. and H. Wial. 2005. "Underemployment in Appalachia and the Rest of the United States, 19962004”, Keystone Research Center, Harrisburg, PA. 


\section{NOTES}

